\title{
New journal for the promotion of Vietnamese environmental research
}

\author{
Tạp chí mói khuyến khích nghiên cứu môi trường ở Việt Nam
}

Editorial

Stefan, Catalin*

Institute of Waste Management and Contaminated Site Treatment, Technische Universität Dresden, Pratzschwitzer Str. 15, 01796 Pirna, Germany

\begin{abstract}
The Vietnamese science and high education system plays a major role in the country's social and economical development. Due to a mixed influence of international education systems, the contribution of the Vietnamese research to the international scientific landscape is still modest. Over the past decades, the most scientific programmes focused mostly on rather theoretical sciences and less on applied sciences. The results are reflected by a rather low rate of international publications on experimental science. Together with the country's efforts on the efficient use of natural resources, there is an urgent demand for strengthening the scientific activity on environmental sciences. The new Journal of Vietnamese Environment was created to respond to the increasing interest in environmental research. The journal was founded as part of an academic network initiated by the Dresden University of Technology in the framework of Vietnamese-German cooperation programs on training and education. With multidisciplinary fields of interest and several types of manuscripts, the journal has a predominant academic character, the submission of manuscripts is open to students, graduates, researchers and staff members of research and academic institutions, as well as to any individual willing to disseminate the knowledge about the management of Vietnamese environment.
\end{abstract}

Hệ thống khoa học và giáo dục đại học Việt Nam đóng vai trò quan trọng trong sụ phát triển kinh tế và xã hội của đất nước. Trong xu hướng giao thoa mạnh mẽ giũa các hệ thống giáo dục quốc tế, đóng góp của các nhà nghiên cúu ở Việt Nam cho cộng đồng khoa họ quốc tế còn khiêm tốn. Trong nhũng thập niên qua, hầu hết các hoạt động khoa hoc tập trung vào khoa hoc lý thuyết hơn là các lĩnh vưc khoa học ứng dụng. Điều này đã được phản ánh qua tỷ lệ khá thấp các ấn phẩm quốc tế về khoa học thực nghiệm. Cùng với nhũng nồ lục của đất nước để sủ dụng hiệu quả các nguồn tài nguyên thiên nhiên, một nhu cầu cấp bách đặt ra là tăng cuờng các hoạt động nghiên cứu về khoa họ môi truờng. Tạp chí Môi truờng Việt Nam ra đời nhằm hương úng sụ quan tâm ngày một gia tăng trong nghiên cúu môi trương. Tạp chi được thành lập nhu một phần của mạng luói học thuật được đề xuất bởi Truờng Đại học Tổng hợp Kỹ Thuật Dresden trong khuôn khổ chuoong trình hơp tác Việt Nam - CHLB Đức về đào tạo và giáo dục. Vói mối quan tâm đa ngành và đa dạng trong ấn phẩm, tạp chi chủ yếu mang tính học thuật, co hội gưi đăng bài viết mở rộng cho cả sinh viên, kỹ su / củ nhân, nghiên cứu viên và các thành viên của Viện nghiên cúu và giáo dục, các cá nhân có mong muốn phổ biến kiến thức về quản lý môi truờng ở Việt Nam.

Keywords: education system, research, publication, journal, environment

\section{Introduction}

\subsection{Historical practice of science in Vietnam}

Built on a solid Confucianist foundation more than one thousand years ago, the high education always played a major role in Vietnam's history. Later on, the science and the high education were confronting the traditional learn- ing systems with visionary concepts during the French colonial times. The country's division in North and South allowed further development of two different education systems and scientific communities. While in the north the education system was influenced by the Soviet model, the scientific programmes were mostly oriented on pure sciences such as physics and mathematics and less on applied sciences. The explanation for this may come from the mostly agricultural profile of the country, with little 
modern industry able to absorb scientists trained on applied sciences (Woodside, 1983). In contrary, the southern education system was still linked to the colonial French models and received more and more influence from the USA. The research institutes were smaller, more flexible and scattered all over the country in comparison to the mono-disciplinary, unitary research centres in the north. After reunification, the country's leaders faced the difficult mission of blending two different higher education systems. Allegedly, the decision was to tailor the southern model after the northern one and thus to cut the links between the Vietnamese scholars in the south and those in the western countries (Abuza, 1996). This led to a continuation of an education and research strategy based rather on a more theoretical approach than on technical, development-oriented missions.

\subsection{Research in transition}

After the introduction of Doi Moi in 1986 and the fall of USSR in 1991, the scientific landscape slowly moved away from the Soviet model towards a more applied approach. Recently, the government made a significant commitment to reform the higher education system by releasing the Higher Education Reform Agenda (Resolution 14/2005/NQ-CP), Vietnam's master plan for higher education up to the year 2020. In line with the rapid industrialisation tendency, the national strategy is focusing on the development of a knowledge-based economy in parallel with the efficient use of natural resources and the environmental protection.

\subsection{Scientific publications}

\subsubsection{Vietnamese research in the international scien- tific landscape}

Despite all efforts, the contribution of Vietnamese research to the international scientific landscape is still modest. This is reflected by the small number of scientific publications in international peer-reviewed journals. As an example, in the period between 1991-2010, the 10 South East Asian (ASEAN) countries: Vietnam, Cambodia, Laos, Thailand, Myanmar, Malaysia, Indonesia, Brunei, Philippines and Singapore published 165,020 original articles in ISI indexed journals, accounting for $0.5 \%$ of the total world scientific papers (Nguyen and Pham, 2011). Within this group, the articles published by Vietnamese scientists accounted to only 6\% (about 9,900 publications). According to VietnamNetBridge (2011), 8,220 articles were published from 2001 to 2010 in ISI indexed journals, meaning that over $80 \%$ of the scientific outcome in the past 20 years was published only in the second decade.

\subsubsection{National scientific publications}

This reduced number of internationally recognized publications does not necessarily mean that the Vietnamese scientists do not published their work. A good number of Vietnamese journals are available online covering different fields of interest from medicine, mathematic, physics, to mechanics, earth sciences or social sciences. The Vietnam Journals Online (VJOL) is a new service maintained by the national Centre for Scientific and Technological Information (NACESTI) under the Ministry of Science and Technology (MOST) promoting the online access to Vietnamese published research. VJOL is currently listing 23 journals on its internet portal (http://www.vjol.info) with 1,473 online articles whereof 1,010 are available in full text (PDF). Without being complete, Table 1 is providing a selection of scientific journals available online in Vietnamese language (partially also in English).

Table 1. Selection of Vietnamese journals

\begin{tabular}{|l|l|l|}
\hline Journal name & Publisher & ISSN \\
\hline Vietnam Journal of Forest Science & Forest Science Institute of Vietnam & n.a. \\
\hline Journal of Scientific Activities & n.a. & $0866-7179$ \\
\hline Vietnam Journal of Mathematics & Institute of Mathematics & $1859-004 \mathrm{~V}$ \\
\hline Vietnam Economic Management Review & Central Institute for Economic Management & $0866-7136$ \\
\hline Vietnam Journal of Mechanics & Vietnam Academy of Science and Technology & $1859-1434$ \\
\hline Vietnamese Journal of Primatology & Endangered Primate Rescue Centre & $0886-8647$ \\
\hline Review of Social Sciences Information & Institute of Social Sciences Information & $0866-8612$ \\
\hline Vietnam Journal of Science & n.a. & $0866-7144$ \\
\hline Vietnam Journal of Chemistry & Vietnam Academy of Science and Technology & $0866-7187$ \\
\hline Journal of Sciences of the Earth & n.a. & $0866-708 X$ \\
\hline Journal of Science and Technology & Vietnam Academy of Science and Technology & $0866-7632$ \\
\hline Philosophy & Vietname Academy of Social Sciences & $0866-8647$ \\
\hline Social Sciences Information Review & Vietname Academy of Social Sciences & n.a. \\
\hline Vietnam Journal of Public Health & Vietnam Public Health Association & $1745-0764$ \\
\hline Vietnam Business Forecast Report & n.a. & $1859-1450$ \\
\hline Vietnam Library Journal & National Library of Vietnam & $1859-2929$ \\
\hline Journal of Information and Documentation & National Centre for Scientific and Technological & \\
\hline Journal of Psychology & Information and Documentation & $1859-0098$ \\
\hline $\begin{array}{l}\text { Journal of Science and Technology Develop- } \\
\text { ment }\end{array}$ & Vietnam Academy of Social Sciences & $1859-0128$ \\
\hline Historical Studies & Vietnam National University HCMC & $0866-7497$ \\
\hline Journal of Research and Development & Department of Science and Technology, Hue & $1859-0152$ \\
\hline
\end{tabular}




\begin{tabular}{|l|l|l|}
\hline Journal name & Publisher & ISSN \\
\hline Journal of Family and Gender Studies & Institute of Family and Gender Studies & $1859-1361$ \\
\hline Religious Studies & Vietnam Academy of Social Sciences & $1859-0403$ \\
\hline Vietnam Journal of Biotechnology & Vietnam Academy of Science and Technology & $1811-4989$ \\
\hline Communications in Physics & Vietnam Academy of Science and Technology & $0868-3166$ \\
\hline Economic Studies & n.a. & $0866-7489$ \\
\hline Vietnam Soil Science Journal & Vietnam Society of Soil Science & $0868-3743$ \\
\hline
\end{tabular}
n.a. - not available

\subsubsection{Demand for environmental publications}

The profiles of the journals listed in Table 1 reflect quite well the strengths of the Vietnamese higher education system although the listing is not always relevant since part of the articles are jointly published with international co-authors as result of international grants. However, classical environmental titles are not included in the list. This shows an obvious demand for journals focusing exclusively on environmental management issues, needs confirmed also by a survey conducted by the International Foundation for Science (IFS, 2009). Most of the grantees interviewed (32\%) mentioned 'environment' (including pollution) on the first place of what they consider to be the highest priority research area in Vietnam. The next two places were occupied by biotechnology (27\%) and agriculture (24\%). Despite the very broad offer worldwide on scientific journals addressing environmental research, there is an urgent demand for scientific publications that are accessible to average researchers in Vietnam and that can cover most actual fields of interest in environmental sciences.

\section{Journal of Vietnamese Environment}

The Journal of Vietnamese Environment (JVE) has been newly designed to cover the actual needs of a scientific community oriented more and more towards the sustainable use of natural resources and environmental protection. The JVE is open to all kind of Vietnam-related environmental topics with focus on the following fields of interest: air pollution, climate change, drinking water supply, environmental policies, food and agriculture, groundwater management, land use management, legislative framework, renewable energies, resources management, socioeconomic aspects, urban development, waste management, wastewater and sanitation.

\subsection{About the journal}

The JVE was founded in 2011 as part of an academic network initiated by the Dresden University of Technology in the framework of Vietnamese-German cooperation programs on training and education. Although the journal has a predominant academic character, the submission of manuscripts is open to students, graduates, researchers and staff members of research and academic centers, as well as to any individual willing to disseminate the knowledge about the management of Vietnamese environment. The members of the Editorial Board are young scientists involved in environmental research with experience on the journal's main fields of interest. The submitted manuscripts will be reviewed by our Editorial Board right after the submission (at a later date, a peer-review process will be implemented). The accepted papers will be published as soon as they are received and included in the current issue so the release frequency of new issues depends on the amount of manuscripts received and accepted for publication.

\subsection{Journal policy}

The papers submitted shall describe new findings in the field of environmental management converged from fundamental research studies, experimental work, review and policy papers, as well as short communications and recent event reports.

The JVE offers online content via its internet portal http://dx.doi.org/10.13141/JVE. The accepted papers will be published in html (abstract) and PDF format (full version) on the journal website. The journal's main publication language is English but, in order to maximize the accessibility of the Vietnamese scientific community to the journal's content, the title and the abstract of the articles will be provided also in Vietnamese language. The manuscripts' submission, publication, and access to the online content will follow the Open Access policy and the service will be provided free of charge.

\subsubsection{Types of manuscripts}

\section{Research papers}

The research papers describe the most recent findings on environmental research. The content of the research papers shall include relevant and original work that has not been published previously and is not under consideration for publication elsewhere.

\section{Short communications}

The short communications are concise reports representing a significant contribution to the journal's areas of interest but do not include the whole research work (a short communication paper can be used for example to announce the start or the progress of new research projects, apparition of a new governmental decree etc).

\section{Event reports}

The event reports can be used to briefly describe the content and main output of public events such as conferences, workshops, training courses etc.

\section{Review papers}


The purpose of review papers is to succinctly review the recent progress in a particular topic. The author of a review paper shall therefore provide the reader with an understanding of the topic by discussing the results presented in other recent research studies (the review paper can also provide the review of a book).

\section{Academic abstracts}

The academic abstracts are literally the abstract of graduation theses that match the journal's areas of interest (environment-related and Vietnam-related topics). The publication on the JVE website assumes that the full graduation thesis has been already published elsewhere (in that case only the abstract is required).

\section{Policy papers}

Policy papers express general statements on contemporary policy issues from different environmental fields such as economics, legal issues, etc.

\section{Conclusions}

The newly launched Journal of Vietnamese Environment aims at covering the obvious demand for the promotion of Vietnam-related environmental research. The journal is addressing especially Vietnamese researchers and scientists dealing with challenges in one of the journal's areas of interest. Despite not being ISI indexed yet, the journal accommodates the researchers' needs for international recognition of their work. With its simple submission and fast review process, the journal sets new standards for online publications on resources management and envi- ronmental protection and opens new communication gates between genuine Vietnamese research and international scientific community.

\section{References}

[1] Abuza, Z. 1996. The politics of educational diplomacy in Vietnam: educational exchanges under Doi Moi. Asian Survey 36(6):618-631

[2] IFS 2009. Science in Vietnam. An assessment of IFS grants, young scientists, and the research assessment. International Foundation for Science, Stockholm. ISBN: 978-91-85798-56-8

[3] Nguyen, T.V., Pham, L.T. 2011. Scientific output and its relationship to knowledge economy: an analysis of ASEAN countries. Scientometrics 89(1):107117

[4] St. George, E. 2010. Higher education in Vietnam 1986-1998: education in transition to a new era? Higher Education Dynamics 29:31-49

[5] Vietnamese Government. 2005. Resolution no. 14/2005/NQ-CP on substantial and comprehensive renewal of Vietnam's tertiary education in the 20062020 period

[6] VietnamNetBridge. 2011. Why Vietnam lacks genuine scientists. (http://english.vietnamnet.vn, retrieved on 2011-11-06)

[7] Woodside, A. 1983. The triumphs and failures of mass education in Vietnam. Pacific Affairs 56(3): 401-427 